\title{
PERNAPASAN BUTEYKO DAN ARUS PUNCAK EKSPIRASI PADA PASIEN ASMA
}

\author{
I Kadek Ananta Wijaya $^{(1)}$, I Made Mertha ${ }^{(2)}$, I Gusti Ayu Rasdini ${ }^{(3)}$ \\ ${ }^{1}$ Program Studi Sarjana Terapan Keperawatan Poltekkes Kemenkes Denpasar \\ Denpasar, Bali, Indonesia
}

email: wijayaananta@gmail.com ${ }^{(1)}$,mdmertha69@gmail.com ${ }^{(2)}$,rasdiniari@gmail.com

Abstrak: Asma merupakan gangguan inflamasi kronis di jalan napas. Arus puncak ekspirasi adalah salah satu uji fungsi paru manusia yang digunakan untuk menilai kemampuan fungsi paru dan memberikan gambaran gangguan pada jalan napas. Penelitian ini bertujuan untuk mengetahui pengaruh teknik pernapasan Buteyko terhadap arus puncak ekspirasi pada pasien asma. Jenis penelitian adalahPre- Experimental Design dengan rancangan yang digunakanya itu One-Group Pretest-Posttest menggunakan purposive sampling. Jumlah sampel sebanyak 22 orang. Arus puncak ekspirasi pasien diukur menggunakan peak flow meter. Hasil arus puncak ekspirasi pasien diuji menggunakan uji paired t-test. Hasil penelitian menunjukkan bahwa arus puncak ekspirasi sebelum pemberian teknik pernapasan Buteyko sebesar 75,764\%, dan setelah diberikan teknik pernapasan Buteyko arus puncak ekspirasi pasien menunjukkan peningkatan menjadi sebesar 79,986\%. Berdasarkan hasil penelitian didapatkan nilai $\rho$-value $=0,000<$ alpha (0,05), maka dapat disimpulkan bahwa ada pengaruh pemberian teknik pernapasan Buteyko dapat meningkatkan arus puncak ekspirasi pada pasien asma.

Kata Kunci : Asma, Arus Puncak Pernapasan, Buteyko

Abstract: Asthma is a chronic inflammatory disorder in the airway. The peak expiratory flow rate is one of the human lung function tests used to assess the ability of lung function and provide an image of the airway disorder. This study aims to determine the effect of Buteyko's respiratory technique on peak expiratory flow rate in asthma patients. The type of research is Pre-Experimental Design with One-Group Pretest-Posttest using purposive sampling. The sample size is 22 people. The patient's peak expiratory flow rate is measured using a peak flow meter. The results of peak expiratory flow rate of the patient tested using paired $t$ - test. The results showed that the peak expiratory flow rate prior to Buteyko's respiratory technique of $75.764 \%$, and after given breathing Buteyko's breathing techniques, peak expiratory flow rate of patients showed an increase to equal to 79.986\%.Basedontheresultsoftheresearch, thevalueof $\rho$-value $=0.000<$ alpha (0,05), it can be concluded that there is influence of giving respiratory technique Buteyko can increase the peak expiratory flow rate in asthma patient. It is expected that the hospital to consider implementing Buteyko's breathing techniques for asthma patients.

Keywords: Asthma, Peak Expiratory Flow Rate, Buteyko

JurnalGemaKeperawatan |Volume 13|Nomor 2| 
I Kadek Ananta Wijaya, I Made Mertha dan I Gusti Ayu Rasdini. Desember 2020. 13 (2). 111-119

\section{PENDAHULUAN}

Asma merupakan gangguan inflamasi kronis di jalan napas. Dasar penyakit ini adalah hiperaktivitas bronkus dan obstruksi jalan napas. Gejala asma adalah gangguan pernapasan (sesak), batuk produktif terutama pada malam hari atau menjelang pagi, dan dada terasa tertekan. Gejala tersebut memburuk pada malam hari, adanya alergen (seperti debu, asap rokok) atau saat sedang menderita sakit seperti demam ${ }^{(1)}$. Gejala yang sering terjadi pada asma adalah hiperventilasi atau napas dalam. Hiperventilasi terjadi karena mengembangnya tingkat kedalaman pernapasan melebihi batas normal sehingga memperburuk system pernapasan karena terjadi kehilangan karbondioksida secara progesif. Hal ini dapat menstimulasi terjadinya penyempitan saluran napas dan peningkatan mukus. Sistem pernapasan yang buruk ini dapat menyebabkan tubuh rentan terhadap penyakit. Semua hal tersebut berhubungan dengan bagaimana cara bernapas yang efisien dan benar ${ }^{(2)}$.

Asma merupakan salah satu penyakit terbanyak di dunia. Jumlah penderita asma mencapai 334 juta orang di seluruh dunia dimana asma tidak hanya menyerang negara maju namun juga menyerang negara miskin dan berkembang ${ }^{(3)}$. Prevalensi asma di Indonesia sebanyak 4,5\% dengan penderita laki-laki sebanyak 505.409 orang dan perempuan sebanyak 522.354 orang. Prevalensi asma di Bali pada tahun 2013 menempati peringkat ke-6 di Indonesia yaitu 6,2 per 1000 populasi penduduk yang mengalami peningkatan dari tahun 2007 yaitu 3,7 per 1000 populasi penduduk ${ }^{(4)}$. Badung merupakan salah satu daerah yang mengalami peningkatan penderita asma setiap tahunnya. Data Rekam Medik RSUD Mangusada menunjukkan pada tahun 2014 pengidap asma yang tercatat di instalasi gawat darurat RSUD Mangusada sebanyak 494 orang, tahun 2015 sebanyak 568 orang, dan pada tahun 2016 sebanyak 767 orang.

Masalah utama yang sering ditemukan pada pasien asma adalah kesulitan dalam melakukan ekspirasi. Perubahan volume udara yang diekspirasi dapat diukur secara obyektif dengan arus puncak ekspirasi. Arus puncak ekspirasi adalah salah satu uji fungsi paru manusia yang digunakan untuk menilai kemampuan fungsi paru, mengetahui besar volume udara paru-paru saat inspirasi dan ekspirasi, serta dapat memberikan gambaran gangguan pada jalan napas dan beratnya serangan asma. Pengukuran arus puncak ekspirasi (APE) dilakukan menggunakan peak flow meter (PFM) dengan menarik napas sedalam-dalamnya kemudian menghembuskan udara ke alat tersebut dengan kuat ${ }^{(5)}$. Nilai normal APE sekitar $80 \%$ sampai $100 \%$ dari nilai normal atau nilai prediksi ${ }^{(6)}$.

Beberapa penelitian menunjukkan penurunan arus puncak ekspirasi pada pasien asma. Penelitian terhadap 32 sampel menunjukkan penurunan APE pada pasien asma yaitu 10 responden menunjukkan APE pada zona hijau (80\% sampai 100\%), 22 responden pada zona kuning (50\% sampai $80 \%)^{(7)}$.

Pengontrolan terhadap gejala asma dapat dilakukan dengan cara menghindari allergen pencetus asma serta menggunakan terapi nebulisasi dengan menggunakan obat agonis-beta sertadiberikan obat anti-inflamasi lain seperti kortikosteroid ${ }^{(2)}$. Sampai saat ini Instalasi Gawat Darurat RSUD Mangusada Badung memberikan terapi oksigen sebagai penanganan pertama kemudian diberikan terapi nebulisasi dengan obat-obatan agonis beta maupun anti inflamasi.

Meskipun terapi secara farmakologis sudah diberikan, arus puncak ekspirasi pada pasien tersebut meningkat namun belum 
I Kadek Ananta Wijaya, I Made Mertha dan I Gusti Ayu Rasdini. Desember 2020. 13 (2). 111-119

sampai pada nilai normal APE pasien. Hasil studi pendahuluan di IGD RSUD Mangusada Badung terhadap 10 pasien asma didapatkan nilai arus puncak ekspirasi minimum sebesar $58,2 \%$, nilai maksimum sebesar $78,4 \%$, ratarata sebesar $72,189 \%$ dengan standar deviasi 6,561. Penurunan arus puncak ekspirasi ini mengakibatkan pengeluaran $\mathrm{CO} 2$ pada alveolus inadekuat sehingga terjadi penurunan perbedaan tekanan parsial alveoli dan kapiler yang nantinya akan mengakibatkan terhambatnya proses difusi. Proses difusi yang terhambat akan menyebabkan hipoksemia dan apabila tidak ditangani akan berlanjut menjadi hiperkapnia dan paling parah yaitu asidosis respiratorik atau gagal nafas ${ }^{(8)}$.

Pengontrolan asma tidak hanya dilakukan melalui terapi farmakologis melainkan dengan terapi komplementer misalnya teknik Pernapasan, teknik relaksasi, akupuntur, chiropatic, serta hypnosis. Salah Teknik pernapasan Buteyko merupakan salah satu teknik pernapasan yang dapat diberikan pada pasien asma. Teknik pernapasan Buteyko adalah serangkaian teknik pernapasan yang bertujuan untuk mengurangi hiperventilasi melalui penurunan frekuensi napas, yang dikenal dengan slow breathing dan reduced breathing, dikombinasikan dengan waktu menahan napas, yang dikenal dengan control pauses ${ }^{(9)}$.

Teknik pernapasan ini terutama digunakan sebagai teknik alami untuk menrunkan gejala asma dan keparahan asma. Selain itu, teknik pernapasan Buteyko digunakan oleh para pasien asma untuk menurunkan ketergantungannya terhadap obat. Metode ini juga bisa digunakan untuk penyakit saluran pernapasan lain termasuk empiema dan bronchitis ${ }^{(10)}$. Teknik pernapasan ini juga dapat meningkatkan fungsi paru dalam memperoleh oksigen dan mengurangi hiperventilasi paru.
Penelitian menyatakan teknik pernapasan Buteyko merupakan salah satu teknik olah napas yang bertujuan untuk menurunkan ventilasi alveolar terhadap hiperventilasi paru penderita asma ${ }^{(11)}$. Oksigenasi yang lancer akan menurunkan kejadian hipoksia, hiperventilasi dan apnea saat tidur pada penderita asma. Metode Pernapasan Butekyo juga memberikan pengaruh terhadap pasien asma yang sedang mengalami terapi kortikosteroid inhalasi yaitu mengurangi penggunaan terapi pengobatan tersebut ${ }^{(10)}$. Penelitian Santoso (2006) menjelaskan Pemberian teknik pernapasan Buteyko secara teratur akan memperbaiki buruknya system pernapasan pada penderita asma sehingga akan menurunkan gejala asma ${ }^{(12)}$. Penelitian ini bertujuan untuk menganalisa pengaruh teknik pernapasan Buteyko terhadap arus puncak ekspirasi pada pasien dengan asma di UGD RSUD Mangusada.

\section{METODE}

Penelitian ini merupakan penelitian pre-eksperimental dengan menggunakan rancangan one-group pre-post test. Pengukuran arus puncak ekspirasi dilakukan sebelum dan setelah diberikan teknik pernapasan Buteyko. Sampel dalam penelitian ini adalah pasien asma yang telah memenuhi criteria inklusi dan eklusi dengan jumlah sampel 22 orang. Instrumen yang digunakan dalam pengumpulan data adalah alat peak flow meter dengan spesifikasi 0800L/menit yang sudah dikaliberasi dan valid serta panduan lembar cek list pengukuran nilai arus puncak ekspirasi. Data yang didapat dianalisa secara univariate dan bivariate. Data pre dan post test selanjutnya dilakukan uji paired t-test untuk mengetahui pengaruh teknik pernapasan Buteyko terhadap arus puncak ekspirasi. 
I Kadek Ananta Wijaya, I Made Mertha dan I Gusti Ayu Rasdini. Desember 2020. 13 (2). 111-119

\section{HASIL DAN PEMBAHASAN}

Tabel 1

Karakteristik Responden Berdasarkan Umur

\begin{tabular}{ccccc}
\hline Variabel & Mean & SD & $\begin{array}{c}\text { Min- } \\
\text { Mak }\end{array}$ & $95 \%$ CI \\
\hline Umur & 43,82 & 12,17 & $26-65$ & $38,42-$ \\
& & & 49,21 \\
\hline
\end{tabular}

Berdasarkan table 1 terlihat bahwa rata-rata umur pasien asma adalah 43,82 tahun $(95 \%$ CI: 38,42-49,21) dengan standar deviasi 12,168 tahun, umur pasien termuda 26 tahun sedangkan umur tertua 65 tahun. Dari hasil estimasi interval dapat disimpulkan bahwa 95\% diyakini bahwa rata-rata umur diantara 38,42 sampai dengan 49,21 tahun.

Tabel2

Karakteristik Responden Berdasarkan Jenis Kelamin

\begin{tabular}{ccc}
\hline $\begin{array}{c}\text { Jenis } \\
\text { Kelamin }\end{array}$ & Frekuensi & Persentase \\
\hline Laki-laki & 10 & $45,5 \%$ \\
\hline Perempuan & 12 & $54,5 \%$ \\
\hline Total & 22 & $100 \%$ \\
\hline
\end{tabular}

Berdasarkan tabel 2 di atas dari 22 responden didapatkan jenis kelamin laki-laki sebanyak $45,5 \%$ dan jenis kelamin perempuan sebanyak $54,5 \%$.

Tabel 3

Karakteristik Responden Berdasarkan Tinggi Badan

\begin{tabular}{ccccc}
\hline $\begin{array}{c}\text { Variabe } \\
1\end{array}$ & $\begin{array}{c}\text { Mean }(\mathrm{cm} \\
)\end{array}$ & $\begin{array}{c}\mathrm{SD}(\mathrm{cm} \\
)\end{array}$ & $\begin{array}{c}\text { Min } \\
-\end{array}$ & $\begin{array}{c}95 \% \\
\mathrm{CI}\end{array}$ \\
& & & Mak & \\
\hline Tinggi & 160,73 & 4,53 & $154-$ & 158,72 \\
Badan & & & 169 & -
\end{tabular}

162,73

Tabel 3 di atas menyatakan rata-rata tinggi badan pasien asma adalah $160,73 \mathrm{~cm}$ (95\% CI: 158,72-162,73 cm) dengan standar deviasi 4,527. Tinggi pasien terendah $154 \mathrm{~cm}$ dan pasien tinggi pasien tertinggi $169 \mathrm{~cm}$. Berdasarkan hasil estimasi interval dapat disimpulkan bahwa 95\% diyakini bahwa rata-rata tinggi badan pasien asma antara $158,72 \mathrm{~cm}$ sampai dengan $162,73 \mathrm{~cm}$.

Tabel 4

Arus Puncak Ekspirasi Responden Sebelum Pemberian Teknik Pernapasan Buteyko

\begin{tabular}{ccccc} 
Variabel & Mean & SD & $\begin{array}{c}\text { Min- } \\
\text { Mak }\end{array}$ & $\begin{array}{c}95 \% \\
\text { CI }\end{array}$ \\
\hline Arus & 75,76 & 6,87 & $63,68-$ & $72,72-$ \\
Puncak & & & 85,75 & 78,81
\end{tabular}

Ekspirasi

Tabel 4 menunjukkan dari 22 responden didapatkan rata-rata arus puncak ekspirasi responden adalah 75,764\% (95\% CI: $72,72-78,81 \%)$ dengan standar deviasi $6,872 \%$, arus puncak ekspirasi responden terendah adalah 63,68\% dan arus puncak ekspirasi tertinggi adalah $85,75 \%$. Berdasarkan hasil estimasi interval dapat disimpulkan bahwa 95\% diyakini bahwa rata-rata arus puncak ekspirasi sebelum pemberian teknik pernapasan Buteyko antara 72,72\% sampai dengan 78,81\%.

Pengukuran arus puncak ekspirasi bertujuan untuk mengukur faal paru secara obyektif dan dapat menunjukkan adanya penurunan kemampuan fungsi paru ${ }^{(8)}$. Perubahan paru secara fisiologis terjadi terdiri dari tiga kondisi yaitu penurunan kekuatan otot pernapasan, penurunan elastic recoil, dan peningkatan kekakuan dinding $\operatorname{dada}^{(13)}$.

Rata-rata arus puncak ekspirasi pasien sebelum pemberian teknik pernapasan Buteyko yaitu $75,764 \%$ yang jika di interpretasikan bahwa arus rata- rata 22 responden mengalami obstruksi ringan (APE 60-80\%). Hasil ini hamper sama dengan penelitian tentang"Gambaran Nilai Peak Expiratory Flow Rate pada pasien Asma yang Mengikuti Senam Asma di PekanbaruTahun 2015" yang menunjukkan 
I Kadek Ananta Wijaya, I Made Mertha dan I Gusti Ayu Rasdini. Desember 2020. 13 (2). 111-119

hasil pengukuran dimana dari 32 orang didapatkan 10 orang mengalami obstruksi ringan (APE 60\%-80\%), 10 orang dengan nilai normal, obstruksi sedang sebanyak 8 orang dan 4 orang mengalami obstruksi berat $^{(7)}$. Peneliti beranggapan bahwa hasil tersebut didapatkan berbeda karena perbedaan kondisi pasien yang dating ke IGD merupakan pasien yang sedang mengalami serangan asma, sedangkan pada poliklinik pasien yang dating merupakan pasien yang sudah teratur berobat.

Berat ringannya obstruksi yang terdapat pada pasien asma berkaitan dengan proses airway remodeling yaitu proses inflamasi kronik pada asma yang menimbulkan kerusakan jaringan secara fisiologis akan diikuti oleh proses penyembuhan (Healing process) yang menghasilkan perbaikan dan pergantian selsel mati atau rusak dengan sel-sel yang baru. Proses penyembuhan tersebut melibatkan regenerasi atau perbaikan jaringan yang rusak dengan jenis sel parenkim yang sama dan mengganti jaringan yang rusak dengan jaringan penyambung yang menghasilkan jaringan skar. Pada asma terdapat saling ketergantungan antara proses inflamasi dengan airway remodeling ${ }^{(3)}$.

Hasil penelitian ini juga diperkuat hasil penelitian tentang Gambaran Efikasi Diri dan Peak Expiratory Flow Rate Pasien Penyakit Paru Obstruksi Kronis (PPOK) Tahun 2017 yang menyatakan bahwa peningkatan proses pernapasan yang meningkatkan penggunaan otot-otot pernapasan dapat menyebabkan hipoksia pada tubuh serta pada otot pernapasan sehingga akan terjadi metabolism anaerob yang akan menghasilkan asam laktat yang dapat menyebabkan kelelahan otot. Hal inilah yang menyebabkan penurunan nilai arus puncak ekspirasi ${ }^{(14)}$.

Perubahan struktur saluran napas yang terjadi adalah hipertrofi dan hyperplasia otot polos. jalan napas, kelenjar mukus. Konsekuensi klinis dari mekanisme airway remodeling di atas adalah peningkatan gejala asma seperti hiperresponsif jalan napas, masalah reganan jalan napas dan obstruksi jalan napas. Sehingga pemahaman airway remodeling bermanfaat dalam manajemen asma dalam pengobatan terhadap obstruksi jalan napas tersebut.

Tabel 5

Arus Puncak Ekspirasi Responden Setelah Pemberian Teknik Pernapasan Buteyko

\begin{tabular}{lllll} 
Variabel & Mean & SD & $\begin{array}{l}\text { Min- } \\
\text { Mak }\end{array}$ & $\begin{array}{l}95 \% \\
\text { CI }\end{array}$ \\
\hline Arus & 79,99 & 6,94 & $67,32-$ & $76,91-$ \\
Puncak & & & 89,96 & 83,06 \\
Ekspirasi & & & & \\
\hline
\end{tabular}

Tabel 5 menunjukkan dari 22 responden didapatkan rata-rata arus puncak ekspirasi responden adalah 79,986\% (95\% CI: 76,91-83,06\%) dengan standar deviasi $6,940 \%$, arus puncak ekspirasi responden terendah adalah $67,32 \%$ dan arus puncak ekspirasi tertinggi adalah $89,96 \%$. Berdasarkan hasil estimasi interval dapat disimpulkan bahwa 95\% diyakini bahwa rata-rata arus puncak ekspirasi setelah pemberian teknik pernapasan Buteyko antara $76,91 \%$ sampai dengan $83,06 \%$.

Hasil pengukuran nilai APE setelah diberikan teknik pernapasan Buteyko yaitu teknik pernapasan Buteyko dilakukan untuk merilekskan otot pernapasan dan iga secara perlahan yaitu adanya peregangan ke arah luar selama inspirasi dan penarikan iga ke arah dalam selama ekspirasi. Pasien dianjurkan untuk mengurangi melakukan pernapasan melalui mulut, tetapi lebih diutamakan untuk melakukan pernapasan melalui hidung $^{(14)}$.

Keadaan patologis yang sering memengaruhi arus puncak ekspirasi adalah gangguan struktur atau fungsi saluran 
I Kadek Ananta Wijaya, I Made Mertha dan I Gusti Ayu Rasdini. Desember 2020. 13 (2). 111-119

respiratorik intratorakal yang meningkatkan resistensi udara, Arus puncak ekspirasi juga terganggu dengan adanya obstruksi saluran ekstratorakal, kondisi yang membatasi pergerakan dinding dada atau fungsiotot-otot pernapasan dan integritas system saraf. Hilangnya volume paru disebabkan oleh meningkatnya recoil paru. Mekanisme pernapasan pada lansia mengakibatkan terjadinya penurunan massa dan kekuatan otot pernapasan, penurunan kompliansi dinding dengan tanda klinis menurunan frekuensi aliran ekspirasi ${ }^{(15)}$.

$$
\text { Teknik pernapasan Buteyko }
$$

merupakan salah satu latihan pernapasan yang membantu merelaksasikan otot, pernapasan, mengembalikan fungsi paru dalam memperoleh oksigen dan mengurangi hiperventilasi paru sehingga serta dapat meningkatkan arus puncak ekspirasi.

Rata-rata arus puncak ekspirasi pada pasien asma setelah pemberian teknik pernapasan Buteyko yaitu 79,986\% yang jika diinterpretasikan berada pada kategori obstruksi ringan. Hasil ini membuktikan bahwa terjadi peningkatan arus puncak ekspirasi yang dibandingkan dengan sebelum pemberian teknik pernapasan Buteyko namun belum dapat meningkatkan rata-rata arus puncak ekspirasi pada pasien asma menjadi normal (APE 80-100\%). Hasil ini berbeda dengan penelitian yang berjudul " Pengaruh Diaphragmatic Breathing Exercise terhadap fungsi pernapasan (RR dan APE) pada lansia di UPT PSLU Kabupaten Jember Tahun 2015“ yaitu 84,95\% arus puncak ekspirasinya normal ${ }^{(16)}$. Perbedaaan hasil penelitian ini dikarenakan perbedaan lamanya pemberian latihan napas dimana pada penelitian ini dilakukan selama satu kali sedangkan pada penelitian Pangestuti dilakukan selama 14 kali sehingga arus puncak ekspirasi yang dihasilkan pun berbeda dikarenakan otot pernapasan akan lebih elastic jika dilatih secara terus menerus yang menyebabkan peningkatan arus puncak ekspirasi yang lebih optimal.

Tabel 6

Pengaruh Teknik Pernapasan Buteyko

Terhadap Arus Puncak Ekspirasi Pada

Pasien Asma

\begin{tabular}{|c|c|c|c|c|}
\hline $\begin{array}{l}\text { Variabel } \\
\text { Arus } \\
\text { Puncak } \\
\text { Ekspirasi }\end{array}$ & Mean & SD & $\mathrm{SE}$ & $\begin{array}{l}p- \\
\text { value }\end{array}$ \\
\hline $\begin{array}{l}\text { Sebelum } \\
\text { Perlakuan }\end{array}$ & 75,76 & 6,87 & 1,47 & 0,000 \\
\hline $\begin{array}{l}\text { Setelah } \\
\text { Perlakuan }\end{array}$ & 79,99 & 6,94 & 1,48 & \\
\hline
\end{tabular}
responden didapatkan rata-rata arus puncak ekspirasi sebelum diberikan teknik pernapasan Buteyko adalah 75,764\% dengan standar deviasi $6,872 \%$. Pengukuran setelah diberikan teknik pernapsan Buteyko didapatkan rata-rata arus puncak ekspirasi sebesar 79,986\% dengan standar deviasi $6,940 \%$. Terlihat perbedaan mean antara sebelum dan setelah pemberian teknik pernapasan Buteyko sebesar 4,222\%. Hasil uji statistic didapatkan nilai p 0,000 maka dapat disimpulkan bahwa terdapat perbedaan yang signifikan pada arus puncak ekspirasi sebelum dan sesudah pemberian teknik pernapasan Buteyko. Nilai p-value yang mana lebih kecil daripada $\alpha$ sehingga Ho ditolak yang berarti terdapat pengaruh pemberian teknik pernapasan Buteyko terhadap arus puncak ekspirasi pada pasien dengan asma.

Secara teori dinyatakan bahwa obstruksi saluran napas yang berat dapat secara fungsional mengurangi kelenturan system pernapasan dengan menyebabkan terjadinya hiperinflasi dinamik. Berulangnya ekshalasi tak sempurna selama bernapas tenang, kapasitas residu fungsional menjadi meningkat secara dinamis, kadang hingga 
I Kadek Ananta Wijaya, I Made Mertha dan I Gusti Ayu Rasdini. Desember 2020. 13 (2). 111-119

mendekati kapasitas total paru. Pada volume tinggi ini system pernapasan menjadi kurang lentur dibandingkan pada volume ketika bernapas normal, dan karenanya kerja elastic dalam setiap kali bernapas meningkat ${ }^{(5)}$.

Penelitian dengan judul "Comparison of the Effect of Buteyko and Pranayama Breathing Techniques on Quality of Life in Patients with Asthma-a Randomized Controlled Trial in 2013" menunjukkan bahwa terdapat peningkatan volume ekspirasi paksa dan arus puncak ekspirasi yang disebabkan oleh pengurangan kerja otot pernapasan dan pengurangan volume karbondioksida dalam paru dengan cara mengatur ritme pernapasan ${ }^{(17)}$.

Arus puncak ekspirasi menjadi menurun selama serangan asma karena kesulitan mengeluarkan udara dari paru-paru, hal ini kemudian berlanjut apabila dalam jangka waktu yang panjang dapat menyebabkan barrel chest. Hal ini akan menyebabkan penurunan ventilasi, penurunan tekanan transmural dan berdampak pada pengecilan gradient tekanan transmural $^{(15)}$.

Semakin kecil gradient tekanan transmural yang dibentuk selama inspirasi semakin kecil pula compliance paru ${ }^{(5)}$.Upaya bernapas meningkat secara bermakna karena kebutuhan akan peningkatan ventilasi substansial, peningkatan beban mekanis yang abnormal, kecepatan ventilasi terutama ditentukan oleh kebutuhan untuk membuang karbondioksida. Upaya napas juga meningkat ketika penyakit mengurangi kelenturan system pernapasan atau meningkatkan resistansi terhadap aliran udara ${ }^{(5)}$.

Pemenuhan proses ventilasi yang adekuat, tekanan di dalam paru saja tidak dapat meningkatkan ventilasi, namun dibutuhkan adanya bantuan dari otot pernapasan. Kontraksi otot yang kuat dan lama dapat mengakibatkan kelelahan yang dikenal dengan kelelahan otot. Kelelahan otot terutama disebabkan oleh ketidaseimbangan proses kontraksi dan metabolisme serabut otot untuk terus memberikan hasil kerja yang sama ${ }^{(2)}$.

Latihan pernapasan terbukti dapat meningkatkan kemampuan otot pernapasan, kekuatan otot yang dilatih akan meningkatkan compliance paru dan dapat mencegah kolaps alveoli ${ }^{(5)}$.Kelemahan otot pernapasan dapat mengakibatkan tahanan jalan napas sehingga terjadi penurunan aliran ekspirasi maksimal, pernapasan dengan latihan pernapasan memberikan ruang lebih luas untuk pengembangan paru jika dibandingkan dengan pernapasan biasa. Manfaat dari latihan pernapasan salah satunya teknik pernapasan Buteyko adalah meningkatkan efisiensi pernapasan dengan mengatur laju pernapasan sehingga mengurangi udara yang terperangkap dalam paru.

Teknik pernapasan Buteyko dapat memperbaiki volume oksigen maksimal yang membuat pernapasan menjadi lebih efisien. Otot yang kelelahan tersebut dibantu dengan pengaturan napas sehingga secara bertahap sehingga otot yang kelelahan tersebut kembali beradaptasi dengan ritme pernapasan yang dikehendaki. Otot-otot yang beradaptasi tersebut dapat menggunakan oksigen lebih efisien dan menjadi lebih resisten dalam melakukan aktivitas berkepanjangan tanpa kelelahan namun tidak mengalami kelelahan otot juga hal ini dapat menyebabkan meningkatnya compliance paru.

Hal tersebut didukung oleh penelitian yang berjudul "latihan Pernapasan dengan Metode Buteyko Meningkatkan Nilai Force Expiratory Volume in 1 Second (\%FEV1) Penderita Asma Dewasa Derajat Persisten Sedang Tahun 2007" yang menyatakan bahwa latihan pernapasan Buteyko dapat meningkatkan volume ekspirasi paksa pasien asma disebabkan karena bertambahnya kekuatan otot pernapasan dan elastisitas paru 
I Kadek Ananta Wijaya, I Made Mertha dan I Gusti Ayu Rasdini. Desember 2020. 13 (2). 111-119

dan rangka dada yang menyebabkan berkurangnya tahanan terhadap aliran udara pada saluran napas ${ }^{(11)}$.

\section{SIMPULAN}

Pemberian teknik pernapasan Buteyko 8. berpengaruh terhadap arus puncak ekspirasi pada pasien asma di Instalasi Gawat Darurat RSUD Mangusada ( $p$-value $=0,000<0,05$ ).

\section{UCAPAN TERIMAKASIH}

Ucapan terima kasih kami sampaikan kepada pembimbing institusi, dan Direktur RSUD Mangusada yang telah mengijinkan untuk melakukan penelitian ini

\section{ETIKA PENELITIAN}

Etika penelitian diperoleh di institusi pendidikan Poltekkes Kemenkes Denpasar

\section{SUMBER DANA}

Penelitian ini merupakan penelitian swadana dari peneliti.

\section{DAFTAR RUJUKAN}

1. GINA. Global Strategy for Asthma Management and Prevention. GINA. 2016;

2. Guyton, Hall. Buku Saku Fisiologi Keperawatan. Jakarta: EGC; 2012.

3. Global Asthma Network. The Global Asthma Report 2014. 2014;

4. RISKESDAS. Riset Kesehatan Dasar (RISKESDAS) 2013: Laporan Nasional 2013. Litbang Depkes. 2013;127(3309):1275-9.

5. Sherwood L. Fisiologi Manusia dari Sel ke Sistem. Jakarta: EGC; 2013.

6. Depkes. Pedoman Pengendalian Penyakit Asma. Jakarta: Kementerian Kesehatan Republik Indonesia; 2009.

7. Zibetra F, Munir SM, Bebasari E. Gambaran Nilai Peak Expiratory Flow Rate (PEFR) pada Pasien Asma yang Mengikuti Senam Asma di Pekanbaru.
JOM FK [Internet]. 2015;2(2):1. Available from: https://media.neliti.com/media/publica tions/188648-ID-gambaran-nilai-peakexpiratory-flow-rate.pdf

8. Sudoyo AW. Ilmu Penyakit Dalam. Jilid III,. Jakarta: Interna Publishing; 2010.

9. Brindley JL. Buteyko Practice Diary and Quick Reference Guide. New York: Buteyko Breathing Association; 2010.

10. Nurdiansyah. Pengaruh Teknik Pernapasan Buteyko terhadap Penurunan Gejala Pasien Asma Kota Tanggerang Selatan. 2013;

11. Agustiningsih D, Kafi A, Djunaidi A. Latihan Pernapasan dengan Metode Buteyko Meningkatkan Nilai Force Expiratory Volume in 1 second (\%FEV1) pada Penderita Asma Dewasa Derajat Persisten Sedang. Ber Kedokt Masy. 2007;23(Yogyakarta):52-7.

12. Santoso FM, Harmayetty, Bakar A. Perbandingan Latihan Napas Buteyko Dan Upper Body Exercise terhadap Arus Puncak Ekspirasi pada Pasien dengan Asma Bronkial. Crit Med Surg Nurs J. 2014;2(2):91-8.

13. Dermawan R, Yunus F, Antariksa B. Uji Diagnostik Rasio Tetap Terhadap Batas Bawah Normal VEP 1 KVP untuk Menilai Obstruksi Saluran Napas. J Respirologi Indones. 2013;33(4):210-20.

14. Suprayitno E, Khoiriyati A, Hidayati T. Gambaran Efikasi Diri dan Peak Expiratory Flow Rate Pasien Penyakit Paru Obstruksi Kronis (PPOK). Media Ilmu Kesehat. 2017;6(1):38-45.

15. Potter PA, Perry A. Buku Ajar Fundamental Keperawatan. Volume 2. Jakarta: EGC; 2006.

16. Pangestuti SD, Murtaqib, Widayati N. 
I Kadek Ananta Wijaya, I Made Mertha dan I Gusti Ayu Rasdini. Desember 2020. 13 (2).

$111-119$

Pengaruh Diaphragmatic Breathing Exercise terhadap Fungsi Pernapasan (RR dan APE) pada Lansia di UPT PSLU Kabupaten Jember (The Effect of Diaphragmatic Breathing Exercise on Respiration Function (RR and PEFR) in Elderly at UPT PSLU Jember Regency). e-Jurnal Pustaka Kesehat. 2015;3(1):74-81.

17. Prem V, Sahoo RC, Adhikari P. Comparison of the Effects of Buteyko and Pranayama Breathing Techniques on Quality of Life in Patients with Asthma - a Randomized Controlled Trial. Clin Rehabil. 2013;27(2):13341. 